\title{
Perspectives of Manufacturing Subsidiaries of Foreign Companies in Russia: Frontier, Faubourg or Sticks?
}

\author{
Igor Gurkov a \\ Professor, gurkov@hse.ru \\ Evgeniy Morgunov ${ }^{\text {b; }}$ a \\ Associate Professor; and Professor, morgunove@mail.ru \\ Zokirzhon Saidov ${ }^{\text {a }}$ \\ Senior Lecturer, zsaidov@hse.ru \\ Alexander Arshavsky ${ }^{c}$ \\ Associate Professor, arshav@mail.ru \\ 119571, Russian Federation
}

\begin{abstract}
${ }^{a}$ National Research University Higher School of Economics, 20, Myasnitskaya str., Moscow 101000, Russian Federation ${ }^{\mathrm{b}}$ Moscow School of Social and Economic Sciences (MSSES), 82, bldg 2, Vernadskogo ave., Moscow 119571, Russian Federation ${ }^{c}$ Russian Presidential Academy of National Economy and Public Administration (RANEPA), 82/5, Vernadskogo ave., Moscow
\end{abstract}

\begin{abstract}
W e present the dynamics of the position of Russian manufacturing subsidiaries of Western MNCs in 2012-2016. The analysis is based on interviews with the heads of subsidiaries, a repeated survey of plant managers and on secondary data on subsidiaries' activities. We propose a new portfolio model that desalinates "the core" and "the periphery" of the corporation and further allocates peripheral subsidiaries into several classes depending on intensity of value transfer from and to a subsidiary and the possibility to apply a "standard" set

of instruments for capital allocation decisions. We argue that in the current situation of the Russian economy the only possibility for Russian manufacturing subsidiaries to remain close to the corporate core is to demonstrate high net profitability of assets. Otherwise subsidiaries are downgraded into "sticks". That position enables subsidiary managers to enjoy high autonomy and wide subsidiary mandates, but endanger the long-term perspectives on maintaining innovativeness and competitiveness of subsidiaries.
\end{abstract}

\section{Keywords:}

multinational companies; manufacturing; Russia; sanctions; corporate development; portfolio models; forecast.
Citation: Gurkov I., Morgunov E., Saidov Z., Arshavsky A. (2018) Perspectives of Manufacturing Subsidiaries of Foreign Companies in Russia: Frontier, Faubourg or Sticks?. Foresight and STI Governance, vol. 12, no 2, pp. 24-35. DOI: 10.17323/2500-2597.2018.2.24.35 
$\mathrm{D}$ espite the sanctions and "countersanctions" (or thanks to them), the Russian subsidiaries of international companies still retain key positions in many industries of the Russian economy. In 2012, the share of Russian subsidiaries of Western corporations amounted to $30 \%$ of total Russian consumer product output [Gurkov et al., 2013, p. 79]. Taking into account the more than 300 new production facilities launched by Western companies in Russia in 2012-2016 (200 factories and 108 new production lines launched at existing facilities [Gurkov, Kokorina, 2017]), their role and importance have increased even more, not just in the consumer products segment (food, pharmaceuticals), but also in mechanical engineering (119 new production lines in various sectors), chemistry (37), and construction materials (30).

However, in spite of Western corporations' seemingly steadily growing presence in Russian industry, they face significant problems with current operations and their prospects are unclear. This paper points out the main problems encountered by Russian production facilities of international companies and outlines possible development paths for them.

\section{Data Sources}

This study was conducted in several stages. The first one (2012-2013) was focused on learning about the object of research, i.e., Russian production facilities owned by international corporations. We visited 18 factories owned by 16 companies $^{1}$, interviewed their management teams and toured the production facilities. During the second stage (2014), the focus shifted towards studying the general aspects of operations of the Russian subsidiaries of Western corporations. This involved interviewing executives, surveying managers, and collecting data about particularly important decisions made by international corporations in Russia. In 2014-2016, 20 heads of Russian subsidiaries of international corporations and foreign company executives were interviewed in order to learn about specific features of managing Russian enterprises. Some of these interviews were conducted within the scope of various business forums (the videos are available on YouTube ${ }^{2}$ ), but most of them took place on the corporations' premises and were devoted to particularly complex issues such as the "mandate" of the relevant Russian subsidiary, relations with the head office, and tactical and strategic steps taken by the Russian offices in 2014-2016. ${ }^{3}$ The company manager survey conducted in the middle of 2014 covered 52 CEOs of Russian subsidiaries of international corporations. An emphasis was placed upon the subsidiary's relationship with the parent company. Thirty-six of the participants also took part in the second survey conducted in 2016, which allowed them to assess changes in their firms' economic situation and their relationship with the parent company.

Finally, in 2015 we began to collect information about the construction of new production facilities and the expansion of existing enterprises' capacities owned by international corporations in Russia. An analysis of specialized websites, federal and local media, and national and local TV news allowed us to identify practically all new enterprises launched by Western corporations in Russia between January 2012 and December 2016, along with a significant number of projects on the expanding capacities of their existing factories ${ }^{4}$.

\section{Russian Subsidiaries of International Corporations before the Current Crisis}

In order to correctly estimate the current state of and the prospects for Russian production facilities owned by Western companies, we focused on the period between 2010-2012. This is the period when the basic growth model for Western corporations' Russian production subsidiaries had fully matured and companies began to adjust their growth models to deal with more complex objectives.

The basic growth model is defined as follows:

- setting up not simply advanced production facilities in Russia, but such that would exceed the parent company's average level in terms of production processes, technological culture, and discipline. In a number of cases unique enterprises were built in Russia for the parent company, both in terms of the output and technological level (so-called "dream factories" [Gurkov, 2014, p. 227]);

- using the "small innovations" potential of Russian enterprises to the maximum extent possible (i.e., product modifications, production process improvements, approaches to and techniques of installing and launching new equipment, etc.). Some of such innovations were awarded the best

\footnotetext{
1 The first co-author visited (and conducted interviews at) all of the factories, while others visited 4-6 factories each.

2 See, for example, the interview with Magnus Brännström, CEO, Oriflame Holding AG (available at: https://www.youtu. be/-ruS41ypHzo, last accessed on 20.02.2017), and Maurizio Patarnello, CEO, Nestle Russia (available at: https://www.youtu. be/WTh8WNJjM5Y, last accessed on 20.02.2017). The interviews were recorded in 2014 and 2015 during the Adam Smith Conferences.

3 The conditions of using the information collected during the interviews were becoming increasingly stringent: in 2015 it required partial anonymity, and in 2016 it required complete anonymity, i.e. not just the interviewees' names, but even the names of their companies could not be published.

${ }^{4}$ A launch of a new factory in Russia cannot go unnoticed; all such events are covered by local media. On the other hand, launching a new production line at an existing factory in most cases is treated as a commercial secret.
} 
corporate practice status when Russian-designed technologies and methods were applied at the parent company's other facilities, for example, in the United States [Gurkov, Filippov, 2013];

- the "cascade" development of Russian production facilities, with "launch teams" comprised of the most highly skilled engineers and workers being transferred, on a temporary or permanent basis, from the international corporation's existing Russian facilities to the newly launched factories [Gurkov, 2014];

- fully matured behavioral standards for the staff of Russian subsidiaries of Western companies in order to employ world-level work practices (attention to detail, production discipline, health and safety norms, highly dynamic production processes, constantly learning new knowledge and skills). These behavioral standards were encouraged and promoted by the stability-oriented HR management system adopted by such companies (the preferred use of permanent employment contracts, an emphasis on a guaranteed proportion of remuneration (as opposed to bonuses), strict adherence to stringent health and safety norms, a broad range of compensation benefits, etc.) [Gurkov, 2016a];

- stringent control over investment resources by the head office, even at the most successful Russian subsidiaries [Gurkov et al., 2014]: any project involving the acquisition of new equipment has to be approved by the regional or global head office.

At the same time, in 2011-2012 the top management of the global corporations became aware that the basic growth model of their Russian subsidiaries was rather shaky in terms of its potential for further expansion, and more importantly, for increasing returns. First of all, by that time Western corporations achieved total superiority in a number of sectors: for example, in 2012 they controlled $90 \%$ of the tobacco and car markets, more than $85 \%$ of the Russian beer market, various segments of the construction materials market, etc. Thus, further growth through mergers with and the acquisition of Russian companies became simply impossible (all noteworthy factories or even promising sites were already bought). The remaining opportunities involved the active development or modernization of the existing factories, switching to contract-based production, and increasing the degree of localization by building new factories from scratch. All three of these options were implemented in various industries to a greater or lesser extent. In the construction and decoration materials industry, priority was given to modernizing existing factories and (to a lesser extent) building new ones. In the automotive sector, the construction of new assembly plants and active use of contractors began as early as in the 2000s; however, in 20102012, this strategy was supplemented by increasing the degree of localization (e.g., Ford and Volkswagen have built engine factories) and encouraging international parts and components suppliers to launch production in Russia (Bosch, Nemak, Continental, Fuyou Glass, Fijikura, Schaeffler, etc.). In the food industry, Western corporations have been using contractors since the 1990s, but due to various reasons this was considered an induced policy. Accordingly, in the 2010s, they took active steps to increase the range of products manufactured at their own facilities in line with the contractual approach. As a result, in 2010-2013 the food industry companies focused on advancing and upgrading their existing facilities and optimizing production assets.

Secondly, the sheer scale of Russian operations prompted corporations to extend the mandate of their Russian subsidiaries. The latter were given more autonomy regarding pricing, product naming, promotion techniques, and the composition of the product matrix. At a number of enterprises, capital construction departments were recreated (or their activities stepped up), which were actively involved in selecting equipment suppliers to expand Russian production facilities, supervising the installation of equipment, and accepting the completed production lines and workshops. For some enterprises it was a matter of honor to exceed output targets while adhering to the technological regimes and quality standards. Employees' innovation activities were actively encouraged as well: a worker who proposed an efficient improvement could count on an impressive bonus [Gurkov, Kossov, 2014].

Numerous Western production corporations became aware of Russia's potential as an another (after Ireland, China, and India) location for their corporate R\&D centers, not so much to serve the local market as to help meeting overall corporate demand.

Formally most of the Russian subsidiaries demonstrated sustainable growth and more than acceptable product quality, as well as became sources of new ideas on product range and, notably, production technologies and the organization of work. In terms of informal relations, global head offices of leading international corporations showed a high level of trust in and empathy towards Russian subsidiaries. The high performance figures and empathy level achieved in 2010-2012 favorably distinguished Russian subsidiaries from the overall corporate background, attracting executive management's attention and bringing in investments. The vast majority of Russian offices of major Western industrial corporations invested in the development of the production facilities they controlled in 2012-2013. That was the period when the projects to build new factories (which became operational in 2014-2016) were developed and the work on their implementation began [Gurkov, 2016b].

Generally, by 2012-2013, Russian subsidiaries secured good positions in the (in)formal hierarchies of Western companies. Some of the Russian subsidiaries in effect managed to get rid of their periphery status, while others were confidently moving on from the periphery towards the corporate core. 


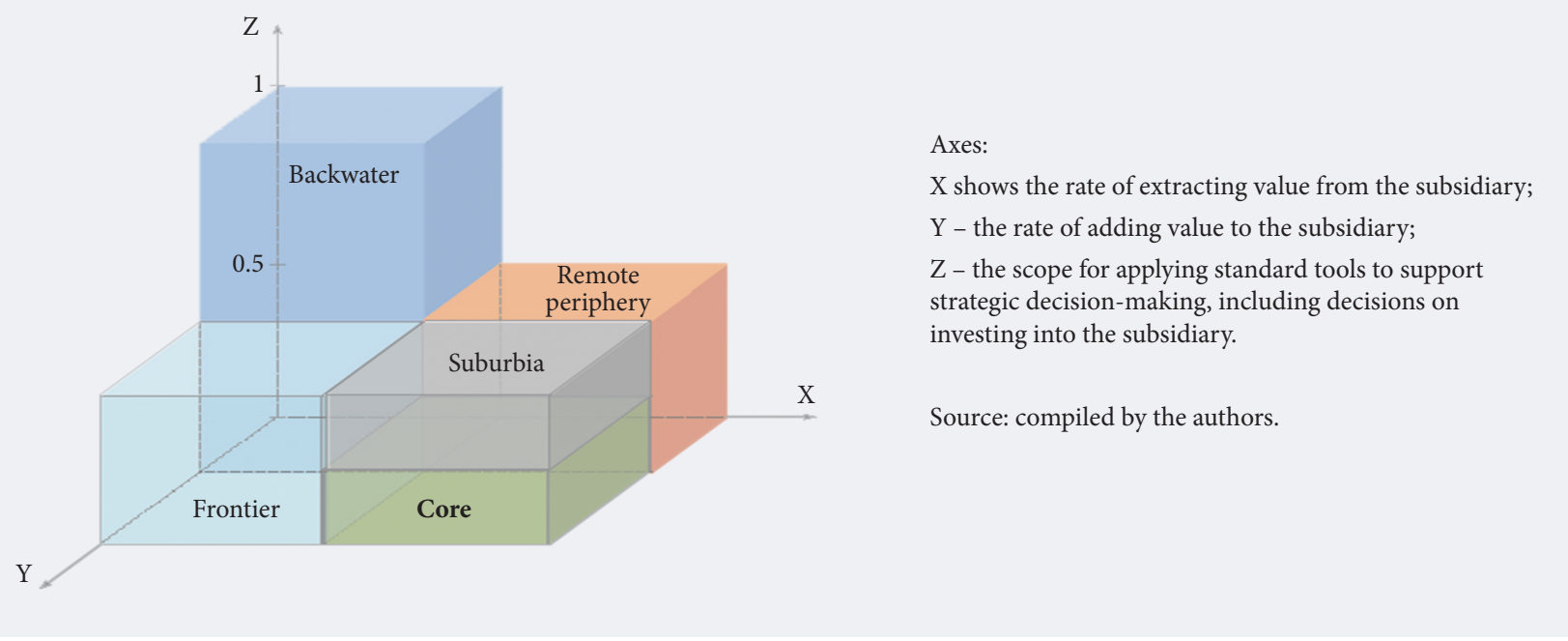

\section{Corporate Periphery and Core}

The "distance" between core and periphery corporate divisions is quite obvious in corporate asset management practices and is quite well described in management textbooks, though it still lacks precise theoretical substantiation.

From a strategic management point of view, it is all very simple. Within the scope of the "business portfolio" model, all areas of activity are broken down using a few easily measured parameters, for example, the growth rate or market share compared with the firm's closest rival (Boston Consulting Group matrix [Henderson, 1984; etc.]). Everything above a certain value is seen as a core business to be supported and developed, while everything else is regarded as periphery businesses which, depending on the circumstances, should be either "milked" (used as a source of revenue to promote the development of core businesses), or liquidated. As they were developed further, portfolio models became increasingly more complex [Nippa et al., 2011], incorporating parameters that could not be explicitly measured, for example, the "degree of matching core corporate competences", "market appeal", and "company strength" [Gurkov, 2001]. This complexity reflected the reality of large corporations' management practices, which indeed clearly delineate core and periphery assets though they do so on the basis of not only objective, but subjective, criteria.

Large corporations commonly use the following parameters to distinguish between their core and periphery assets:

- The ability to fully take into account factors affecting the business and therefore apply standard tools to manage them, especially when making decisions on allocating resources between company divisions [Rust, 1994; Aharoni, 2011; Graham et al., 2015];

- The ability, when the need arises, to quickly add value to, or extract it from a specific company division [see Gurkov, 2015a].

In line with the above parameters, corporate businesses can be divided into five groups, or zones: core, suburbia, frontier, remote periphery, and backwater (Figure 1).

Core: subsidiaries that the parent company constantly exchanges value with, in both directions, and which is suitable for the application of standard capital asset management tools.

Suburbia (close periphery): subsidiaries that the parent company also regularly exchanges value with, in both directions, but these (still) remain unsuitable for the full application of standard capital asset management tools.

Frontier: subsidiaries that are the recipients of value from the head office and other corporate divisions, on the whole, they are suitable for the application of standard investment management tools; however, these investments are not expected to yield immediate returns. Younger corporate subsidiaries can be seen as frontier, whose status and prospects are not yet completely clear. Corporate management may have certain hopes and expectations for them, but these too remain unconfirmed. When they do get confirmed, the frontier subsidiary starts drifting towards the core. Conversely, unmet expectations can push the subsidiary farther away towards the "remote corporate periphery". The frontier may simultaneously include subsidiaries drifting alongside with or towards each other. The frontier can be seen as the most dynamic part of the company. Given sufficiently successful overall business results, the frontier tends to drift towards the corporate core. 
Remote periphery: the subsidiaries that mostly transfer value to the corporate core or to other subsidiaries. Sustainable value extraction first of all requires identifying its sources and to do that, management needs to have specialized knowledge and skills.

Finally, backwater corporate subsidiaries are also worth one's attention. Channelling assets from the corporate core or other subsidiaries into this area is either very difficult or not particularly sensible, since nothing can be extracted back from it. If a decision was made to leave such subsidiaries be, their suitability for the application of standardized strategic investment decision-making tools ceases to matter. During periodic corporate "ballast dropping" exercises, such divisions are liquidated and the costs of closing them down are written off as a general corporate loss ${ }^{5}$. Between such "clean-ups" backwater subsidiaries can drag on for years, if not for decades. In rare and unusually lucky cases (new opportunities arise, employees inspired by new prospects discover new talents), a subsidiary can move out of the backwater into the frontier, and then on into the corporate core. For example, an Austrian tram factory bought by a Canadian snowmobile manufacturer as a tie-in became the basis of the Bombardier Transportation Company (a subsidiary of Bombardier Inc.) - mainly because a group of workers to be made redundant were asked to design a new project and did a spectacular job [Baghai et al., 1997]. In 2014 Bombardier Transportation employed 39,700 people, its annual revenue reached $\$ 9.6$ billion, and the portfolio of orders reached $\$ 32.6$ billion [Bombardier, 2015].

Dividing corporate subsidiaries into "core" and "periphery" is a quite common economic geography tool [Gluckler, 2014; et al.], but it is rarely applied in international business theory. Numerous studies were devoted to analyzing the concept of "distance" (institutional, mental, and psychological) between the head office and international subsidiaries [Ambos el al., 2016; Ando, Paik, 2013; Bae, Salomon, 2010; Berry et al., 2010; Dikova, 2009; Harzing, Pudelko, 2016; Hernández, Nieto, 2015; Johnson et al., 2009; Merchant et al., 2012; Phillips et al., 2009; Salomon, Wu, 2012; Stahl et al., 2016; Xu, Shenkar, 2002]. However, nobody succeeded in merging different kinds of distance into a single model. This was largely because theoretical literature, with very few exceptions [Murphy, Ackroyd, 2013; Schönbohm, Zahn, 2016], pays little attention to issues associated with value extraction.

Meanwhile tension and conflicts at corporations mainly arise between the head office and "remote periphery" specifically, due to the unequal exchange of value between the subsidiary and the parent company. Remote periphery companies frequently cannot accept the "cash cow" role, which explains their desire to draw the head office's attention to their real or imagined potential [Bouquet, Birkinshaw, 2008], or to problems they face trying to create value without receiving substantial support from the "center" [Conroy, Collings, 2016]. In the case that such tactics fail, the subsidiary management may resort to "opportunistic behavior", i.e., they will reduce the efficiency of value creation [Kostova et al., 2017]. Sometimes subsidiaries succeed in stepping down the "center's" requirements concerning the amount of value they must create and move into the "backwater"; but in most cases the corporation simply gets rid of the business that no longer generates profits [Barney et al., 2015; Belderbos, Zou, 2009; Benito, 2005; Berry, 2010; Berry, 2013; Dorrenbacher, Gammelgaard, 2010; Dorrenbacher, Gammelgaard, 2011; McDermott, 2010; Song, 2014].

In the light of the subsequent analysis, we should explain exactly what we mean by "standard tools" for supporting capital investment-related decision-making and which factors affect the circulation of value between the corporate head office and subsidiaries (or between subsidiary companies, i.e., firms owned by the same parent company).

Surveys of the CEOs of approximately 1,000 of the largest international companies conducted in the 2000s allowed us to identify the parameters of the "standard toolset" they use to make decisions concerning the allocation of capital between corporate subsidiaries [Graham et al., 2015, p. 463]:

- net present value (NPV) rank;

- project managers' reputation;

- managers' confidence of success;

- cash flow timing;

- market share;

- top managers' gut feeling.

All of the above tools are typically applied simultaneously. When the external environment becomes more uncertain, using quantitative indicators such as net present value rank and cash flow timing becomes problematic. Top managers' gut feelings move to the forefront. This raises the issue of the partial applicability of standard approaches to decision-making. However, intuition is based upon knowledge, as well as on an understanding of global industry development trends and the "local context" (i.e., specific features of doing business in a particular region, country, etc.) [Ahworegba, 2017]. When the

\footnotetext{
${ }^{5}$ For example, Unilever restructured its business portfolio in 2000 selling some of the brands it owned and closing down more than 100 factories. The brand sale yielded $\$ 642$ million to the corporation, while the closure of the factories cost it $\$ 2.3$ billion, which was written off as a loss [Gurkov, 2008, pp. 138-139].
} 


\section{Table 1. An Incomplete List of Value Types and Ways to Transfer Value within Corporations}

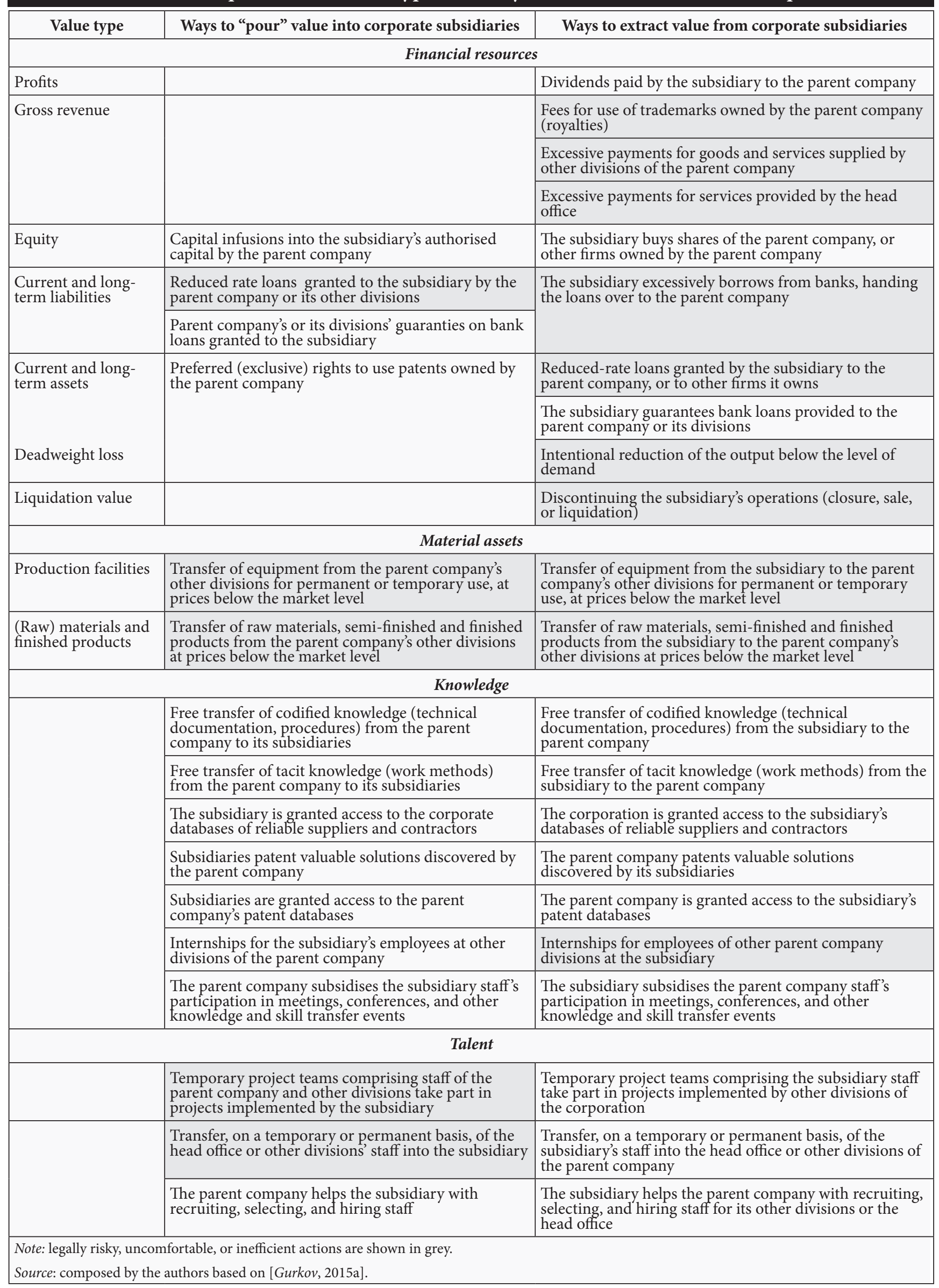


top management lacks such knowledge, when all they can rely on is "confidence of success", standard strategic decision-making support tools become less applicable.

Possible formats that corporations can use to add value to their subsidiaries or extract it from them are presented in Table 1 (for more detail see [Gurkov, 2015a]).

Identifying specific techniques for adding or extracting value as well as explaining their interaction and combined use is a rather notional and imprecise exercise. Under certain conditions, loans provided by parent companies can be converted into the subsidiary company's equity, while members of a temporary "launching team" may become permanent employees. Applying many of the above techniques requires a specific institutional environment, in particular having detailed legislation about intellectual property rights and the sufficient tolerance of tax authorities towards transfer pricing. Being able to quickly transfer staff from one subsidiary to another, on a temporary or permanent basis, is very important for talent circulation. Transferring tacit knowledge above all implies recognizing its value. At international companies this requires overcoming ethnic prejudices and biases, and the promotion that all, no matter one's ethnic background, can suggest valuable ideas that can be applied in other countries too".

On the whole, the suggested model of dividing corporations into core, suburbia, frontier, remote periphery, and backwater allows one to clearly define corporate subsidiaries' prospects following significant changes in economic and institutional conditions in particular countries. Next, we take a look at the processes that were unfolding at Russian production subsidiaries of international companies in 2014-2016 in terms of the actual facts and the proposed corporate structure model.

\section{The War of Sanctions, December 2014's "Black Tuesday", and the Reaction of Parent Companies' Executive Management}

The first wave of Western sanctions did not affect the vast majority of international corporations' Russian subsidiaries. The beginning disruption of economic ties with Ukraine was much more critical. A significant portion of Russian enterprises' production capacities depended upon exporting finished products to that country as well as importing raw materials and components from it. With very few exceptions, the introduction of Russian "counter-sanctions" had a positive effect, first of all, for food industry companies. Even in early December 2014, the management of many Western corporations were cautiously optimistic about the current developments, and when asked "How much money are Russian consumers going to have left to buy your products?", they tended to answer "Enough".

The moment of truth came in the second half of December 2014. The ruble had dropped sharply, electronics stores and car dealerships were hit by panic buying. Russian subsidiaries of Western corporations realized that they would have to revise all their plans for 2015. As the financial director of the Russian office of a leading global consumer products corporation told us in the summer of 2015, "we had a meeting on the 24th of December, took one last look at our wonderful operational plan for 2015 and binned it. Then we started to draft a new one and finished just hours before New Year's Eve. Our assumptions turned out to be $70 \%$ correct" 6 .

The collapse of the ruble happened at a most unfortunate time: at the end of the calendar year, which for most of the Western corporations coincides with the end of the financial one. Due to the devaluation of the ruble, impairment loss was recorded for the 2014 financial year on consolidated corporate balance sheets. Companies who had heavily invested in Russia in the first half of 2014 and had to convert their investments into capital assets before December 31 of the same year faced the most serious problems. Since parent companies' consolidated accounting is maintained in dollars, euros, and other "hard currencies", these investments were practically nullified due to the aforementioned devaluation of the ruble. Against the background of a general decrease in the capital assets of Russian subsidiaries and their affiliates on the corporate balance sheets and the devaluation of the financial results of their activities, this "evaporation of investments" added to the problems managers of Western corporations faced when reporting the 2014 results to their shareholders.

Still, the fact remains that corporate top management deserve near top marks for the tactics they adopted regarding their Russian subsidiaries over the course of the next year. Responsibility for the problems had not been placed on the CEOs of the Russian subsidiaries. On the contrary, summarizing the results of the first quarter of 2015, the heads of the global corporations generally noted that "we have an excellent team in Russia, excellent productivity enhancement programs, sensible pricing policies, and excellent profit management practices" [PepsiCo, 2015]. Of course, the amounts allocated to Russian subsidiaries by head offices in 2015 had dropped, but in practically all cases it was decided to complete the construction of factories that were close to approaching the operational stage. Money was made available to launch specific production lines, workshops, and production facilities that were expected to increase sales by refocusing on segments that still displayed growth trends (e.g., baby food). All in all, between January 2015 and December 2016, Western corporations launched 86 new factories in Russia and completed 59

${ }^{6}$ We interviewed the same respondent again in July 2016. When asked what had changed since our last meeting he said, quite sincerely: "Was that really a year ago? I feel like it's still 2015". 
important projects at existing facilities. Out of the 86 newly launched factories 15 were chemical and pharmaceutical ones, 12 manufactured transport vehicles, 11 belonged in other mechanical engineering industries, nine made construction materials, seven - food stuffs, and six operated in the forest and pulpand-paper industry. Out of the 59 facilities installed at existing plants, 26 specialized in the food industry, seven - in making transport vehicles, and seven - in other mechanical engineering segments.

Notably, the number of sold or closed factories owned by Western corporations was completely incomparable with the sheer scale of decline in demand or with the number of newly opened facilities. Certain markets (beer, juices, cars, railway rolling stock, and locomotives) declined in 2015 by at least 20-30\%. During the next year the contraction continued. Still, despite all this, no more than 16 factories owned by Western corporations were closed or sold in 2015-2016, and they were liquidated in the softest possible way in terms of the treatment of their employees?

During the same period, with active support by the global head offices, Russian subsidiaries tried all "operational and tactical" approaches to coping with shrinking or stagnating markets, in particular:

- the sharp reduction of the product range offered to Russian consumers (some of the Russian subsidiaries of global corporations reduced the range of their products by as much as $40-50 \%$ );

- breaking the product range down into "drivers of sales" (with minimal price increase), and "drivers of revenues" whose prices grew at a rate higher than the average inflation;

- "pulsation" of advertising budgets (sharp reduction, or conversely, dramatic increase of unit advertising costs for specific product groups);

- making use of the government export promotion initiatives;

- participation in import substitution programs.

None of the above (and many other) measures were sufficient to break the overall negative trend: the declining purchasing power of the population, reduced public procurement of civil products, and reduced investment programs of public corporations. Still, they did help many of the international corporations' Russian subsidiaries somewhat improve their situation. Also, throughout 2016, thanks to the strengthening of the ruble, foreign corporations made significant profits converting Russian sales into dollars and euros. Accordingly, the perception of Russian assets by the financial departments of international corporations changed for the better.

\section{Russian Subsidiaries' Position in the Structure of International Corporations}

The overall situation Russian production subsidiaries of international corporations found themselves in can be summarized by a quote attributed to German General Ludendorff about the position of the "Axis Powers" (Germany, the Austro-Hungarian Empire, Bulgaria, and Turkey) in 1918: "The strategic situation... was very hard, but the operational one was quite acceptable, while tactically things were simply excellent" (cit. ex.: [Pereslegin, 1999, p. 480]). From a tactical point of view, Western corporations had by now learned how to operate on stagnating and shrinking markets; operationally, they had identified the precise local market segments that continued to grow, the ones related to declining imports of consumer (especially manufacturing) products and import substitution (pharmaceuticals, agricultural machinery, etc.), along with certain export opportunities for Russian production facilities.

Strategically, however, international corporations recognized the institutional limitations related to adding value to and especially extracting it from their Russian industrial assets. There were no formal grounds to complain: the terms of net profit repatriation from Russia through the payment of dividends were still much more liberal than, for example, in China, while the terms for investing in subsidiaries' authorized capital were much more favorable than, say, in India, until recently. Still, having encountered the need to add value using formats other than investing in equity and extracting it outside the scope of net profit repatriation, Western companies discovered that many such activities either fell into a "grey area", or were fraught with serious economic or moral losses.

For example, the Russian tax authorities and the Ministry of Finance believe that transfer pricing rules are applicable to loan contracts. Therefore, a Russian subsidiary can lend money to the parent company (or to any other corporate structure), but such loans to "interdependent" legal entities have to be provided using "normal market interest rates". Furthermore, the Russian company must inform the tax authorities about such loans and provide documentation confirming that the interest rate was indeed close to the average market level [Lazareva, 2015; etc.].

\footnotetext{
${ }^{7}$ Before closing down its factory near St. Petersburg, GM paid six months' wages to all workers who were made redundant. Closing its Chelyabinsk beer factory, Baltica spent 300 million rubles to lay off 458 workers. The money was used to pay them lump sum compensation (seven average monthly wages), plus vacation money, bonuses for 2014, sickness pay, maternity leave pay, and money to pay job placement agencies that were supposed to help the laid off workers find new jobs (for more detail see: http://obzor.ru/news/baltika-vyplatit-sotrudnikam-zakryvshegosya-v-chelyabinske-zavoda-kompensacii-summa-porazhaet, last accessed on 10.02.2017).

8 Though in most such cases Western corporations were able to successfully defend themselves from the taxman's accusations.
} 
Several cases lost by international companies in Russian courts in 2014-2015 show that repatriating gross revenues (as opposed to net profits) from Russia by paying royalties to the parent company (e.g., for trademarks) involves a high level of risk. Importing and exporting equipment or supplying products at too low prices are fraught with serious customs problems. In some cases, litigation between foreign corporations and Russian tax authorities concerned the provision of head offices' services to local divisions at inflated prices $^{8}$.

The adoption of more strict immigration laws threatened recruiting foreign professionals for work, on a temporary or permanent basis, at Russian enterprises due to the more complex administrative procedures for obtaining work permits.

Hopes to gain additional profits by cutting production capacities did not come true: closing a couple of factories was not enough to balance the market due to the excessively fast contraction. The liquidation value of closed Russian factories in most cases turned out to be negative (see, e.g., footnote 6). In 20152016, three factories were sold, while in some cases the corporations carried on with production at newly launched facilities bearing the significant costs of relocating the workforce from the liquidated plants [Gurkov, Morgunov, 2015]. Thirteen more factories were simply closed; some of them were mothballed, which resulted in additional costs (maintaining security, paying property tax, etc.). The greyed-out sections in Table 1 above show the legally risky, uncomfortable, or inefficient ways to extract value from Russian subsidiaries of international corporations under the current conditions.

Obviously, except for the rare cases of generating sustainably high net profits, in the current crisis, Russian production subsidiaries of international corporations have no chance of remaining in the core, suburbia, or remote periphery zones given that the scope for extracting value from them in any other way than by paying some of their net profits to the parent company remains extremely limited. In the best possible case, if financial and other infusions by the parent company remain in place (primarily due to opening new factories or launching new facilities at existing ones), they have a chance to slide into the frontier. Otherwise, Russian subsidiaries may find themselves in the backwater, with minimal support from parent companies, which many CEOs of such subsidiaries have already experienced. In the survey conducted in the middle of 2014 , between $45-55 \%$ of the managers noted they received significant support from their parent companies and other corporate divisions to implement development projects, develop new products, advance production processes, and retrain personnel [Gurkov, 2015b]. Practically none of the respondents assessed such support as "insignificant".

When the same managers were surveyed in the middle of 2016, the following shares of respondents assessed the support they received from the parent company as significant:

- financial support - 33\%;

- new product development -30\%;

- advancing production processes - 34\%;

- improving personnel $-17 \%$.

At the same time, the shares of respondents who described support by their parent company as "insignificant" were as follows: $28 \%$ for advancing production processes, $37 \%$ for new product development, and $50 \%$ for improving personnel.

Notably, Russian subsidiaries' mandate (i.e., their area of competency) has not been cut down [Birkinshaw, 1996; Birkinshaw, Hood, 1998; Gurkov, 2016c], it remains the same or has actually been extended, so that the subsidiaries have to deal with the problems they face on their own. Potentially, reduced support by the parent company for new product development and especially the advancement of production processes can disrupt the competitive advantages that Russian subsidiaries of Western corporations have over "purely local producers", which would only push them further into the backwater. The lack of interaction with the parent company makes generating new ideas valuable for the whole corporation less likely; accordingly, the perceived value of the local personnel drops. In other words, the last opportunities to transfer value from the subsidiary into the corporation via knowledge or talent are also disappearing.

\section{Conclusions}

During this article, we considered the main problems that the Russian production subsidiaries of international corporations are facing in terms of their position in the parent company's structure after the well-known events of 2014. We proved that in the absence of high profit margins and significant net profits, these firms are doomed to slide into the corporate "backwater". It can turn out to be very comfortable for them, since it provides a high degree of autonomy regarding current operations but it threatens their long-term competitiveness. So far, the process of parent companies' getting rid of subsidiaries with reduced competitiveness has been slowed down by the low liquidity of their assets (no buyers, either foreign or Russian).

If the overall economic situation in Russia improves it may lead to paradoxical developments, in particular, a larger-scale exit of international corporations from Russian assets by selling their factories to Russian firms or to "second rate" international corporations (i.e., those from developing countries). 
When we surveyed companies in 2012-2013, we observed such enterprises: those that have left the leading international corporations to join the second-rate ones.

When a leading international corporation sells an enterprise to a second-rate parent company, the enterprise gets the chance to survive and sustain its production output. However, its productivity and technological efficiency inevitably diminishes given that the enterprise no longer has access to unique know-how and technological solutions supplied by advanced global corporations. Developing new brands or using popular Western ones also becomes problematic: now the companies have to pay real royalties for them to their international owners. Thus, if the objective is to specifically preserve and increase the presence of leading international corporations in Russia, new original solutions should be sought in the economic policy domain in order to increase the appeal of Russian production assets for such investors.

In the middle of 2016, we tried to prepare a number of recommendations concerning how to make Russian production assets more attractive to leading Western corporations. These suggestions were presented at various investment fora [Gurkov, 2016d], and submitted to the Consultative Foreign Investment Board of the Russian Government. Among other things, it was proposed to take steps to improve the quality of secondary vocational training in Russia, which would allow firms to sharply reduce the costs of launching and maintaining advanced production facilities. Another group of recommendations addressed the promotion of the development of Russian suppliers of equipment for international corporations' production facilities. Of course, the aforementioned suggestions do not include an exhaustive list of possible steps that would help Russian subsidiaries of international corporations retain their current status or move closer to the parent company's "core" in order to sustain and improve the technological level of companies operating in particularly important sectors of the Russian industry.

\section{References}

Aharoni Y. (2011) Behavioral elements in foreign direct investment decisions. The Future of Foreign Direct Investment and the Multinational Enterprise. Research in Global Strategic Management, vol. 15, pp. 23-60.

Ahworegba A.H. (2017) The role of local context in headquarters-subsidiaries relationships: A global analysis of the literature. Journal of East-West Business, vol. 23, no 1, pp. 71-103. DOI: 10.1080/10669868.2016.1228554.

Ambos T.S., Ambos B., Birkinshaw J. (2016) Perspectives on headquarters-subsidiary relationships in the contemporary MNC // Research in Global Strategic Management (eds. T.S. Ambos, B. Ambos, J. Birkinshaw), vol. 17, Bingley, UK: Emerald Group Publishing Limited, article III. Available at: http://www.emeraldinsight.com/ doi/pdfplus/10.1108/S1064-485720160000017017, accessed 19.02.2017.

Ando N., Paik Y. (2013) Institutional distance, host country and international business experience, and the use of parent country nationals. Human Resource Management Journa, vol. 23, no 1, pp. 52-71.

Bae J.-H., Salomon R. (2010) Institutional distance in international business research. Advances in International Management, no 23, pp. 327-349.

Baghai M.A., Coley S.C., Farmer R.H., Sarrazin H. (1997) The growth philosophy of Bombardier. McKinsey Quarterly, no 2, pp. 4-29.

Barney J.B., Damaragu N.L., Makhija A.K. (2015) Real options in divestment alternatives. Strategic Management Journal, vol. 36, no 5, pp. 728-744.

Belderbos R., Zou J. (2009) Real options and foreign affiliate divestments: A portfolio perspective. Journal of International Business Studies, no 40, pp. 600-620.

Benito G.R.G. (2005) Divestment and international business strategy. Journal of Economic Geography, vol. 5, no 2, pp. 235-251.

Berry H. (2010) Why do firms divest? Organization Science, vol. 21, no 2, pp. 380-396.

Berry H. (2013) When do firms divest foreign operations? Organization Science, vol. 24, no 1, pp. 246-261.

Berry H., Guillén M.F., Zhou N. (2010) An institutional approach to cross-national distance. Journal of International Business Studies, vol. 41, no 9, pp. 1460-1480.

Birkinshaw J. (1996) How multinational subsidiary mandates are gained and lost. Journal of International Business Studies, vol. 27, no 3, pp. 467-495.

Birkinshaw J., Hood N. (1998) Multinational subsidiary evolution: Capability and charter change in foreign-owned subsidiary companies. Academy of Management Review, vol. 23, no 4, pp. 773-795.

Bombardier Inc. (2015) Sharpening Our Focus. Activity Report 2014, Montreal: Bombardier Inc. Available at: http:// www.bombardier.com/content/dam/Websites/bombardiercom/supporting-documents/Sustainability/Reports/ CSR/Bombardier-Activity-Report-2014-en.pdf, accessed 10.12.2016.

Bouquet C., Birkinshaw J. (2008) Weight versus voice: How foreign subsidiaries gain attention from corporate headquarters. Academy of Management Journal, vol. 51, no 3, pp. 577-601.

\footnotetext{
${ }^{9}$ When launching advanced production facilities, Western companies frequently have to send large groups of local staff (engineers and workers) for long (in excess of one month) on-the-job training at the company's other production facilities abroad.
} 
Conroy K., Collings D. (2016) The legitimacy of subsidiary issue selling: Balancing positive and negative attention from corporate headquarters. Journal of World Business, vol. 51, no 4, pp. 612-627.

Dikova D. (2009) Performance of foreign subsidiaries: Does psychic distance matter? International Business Review, vol. 18, no 1, pp. 38-49.

Dorrenbacher C., Gammelgaard J. (2010) Multinational corporations, inter-organizational networks and subsidiary charter removals. Journal of World Business, vol. 45, no 3, pp. 206-216.

Dorrenbacher C., Gammelgaard J. (2011) Conflicts in headquarters-subsidiary relationships: Headquarters-driven charter losses in foreign subsidiaries. Politics and power in the multinational corporation: The role of institutions, interests and identities (eds. C. Dörrenbächer, M.Geppert), Cambridge: Cambridge University Press, pp. 231-254.

Gluckler J. (2014) How controversial innovation succeeds in the periphery? A network perspective of BASF Argentina. Journal of Economic Geography, vol. 14, no 5, pp. 903-927.

Graham J.R., Harvey C.R., Puri M. (2015) Capital allocation and delegation of decision-making authority within firms. Journal of Financial Economics, vol. 115, no 3, pp. 449-470.

Gurkov I. (2001) Strategicheskii menedzhment organizatsii [Strategic Management of the Organization], Moscow: Intel-Sintez (in Russian).

Gurkov I. (2014) Management practices in Russian manufacturing subsidiaries of foreign multinational corporations: Challenging some beliefs about contemporary Russian industrial management. Post-Communist Economies, vol. 26, no 2, pp. 220-240

Gurkov I. (2015a) Corporate Parenting Styles of the Multinational Corporation: A Subsidiary View. Progress International Business Research (eds. R. van Tulder, A. Verbeke, R. Drogendijk), vol. 10, Bingley, UK: Emerald Group Publishing Limited, pp. 57-78. Available at: http://www.emeraldinsight.com/doi/full/10.1108/S1745886220150000010003 , accessed 18.06.2016.

Gurkov I. (2015b) Russian manufacturing subsidiaries of Western multinational corporations: support from parents and cooperation with sister-subsidiaries. Journal for East-West Business, vol. 21, no 3, pp. 157-181.

Gurkov I. (2016a) Human resource management in Russian manufacturing subsidiaries of multinational corporations. Post-Communist Economies, vol. 28, no 3, pp. 353-372.

Gurkov I. (2016b) Against the wind - New factories of Russian manufacturing subsidiaries of Western multinational corporations. Eurasian Geography and Economics, vol. 57, no 2, pp. 161-179.

Gurkov I. (2016c) Oriflame CIS: The successful evolution of a regional subsidiary's mandate. Global Business and Organizational Excellence, vol. 35, no 4, pp. 44-54.

Gurkov I. (2016d) Investimenti Diretti Stranieri in Russia e Nuove Opportunità, Verona: Conoscere Eurasia Edizioni.

Gurkov I., Filippov S. (2013) Innovation processes in the Russian manufacturing subsidiaries of multinational corporations: An integrated view from case studies. Journal of East-West Business, vol. 19, no 4, pp. 260-290.

Gurkov I., Kokorina A. (2017) Who cut the ribbon? A quantitative analysis of solemn opening ceremonies of new plants of multinational corporations in Russia (SSRN Working Paper). Available at: https://papers.ssrn.com/sol3/papers2. cfm?abstract_id=2917572, accessed 22.02.2017.

Gurkov I., Kossov V., Morgunov E., Saidov Z. (2013) Innovatsionnye praktiki rossiiskikh proizvodstvennykh podrazdelenii mezhdunarodnykh korporatsii - faktory sozdaniya, otbora i rutinizatsii effektivnykh form deyatel'nosti [Innovative Practices of the Russian Manufacturing Subsidiaries of Multinational Corporations - Factors of Efficient Activities Creation and Routinization]. Ekonomicheskaya nauka sovremennoi Rossii [Economics of Contemporary Russia], issues 2 and 4, pp. 76-87, and 76-93 (in Russian).

Gurkov I., Kossov V., Morgunov E., Saidov Z. (2014) Rossiiskie obrabatyvayushchie proizvodstva zarubezhnykh korporatsii: global'nye upravlencheskie praktiki $i$ vozdeistvie na mestnye instituty (Doklad $k$ XV Aprel'skoi mezhdunarodnoi nauchnoi konferentsii po problemam razvitiya ekonomiki i obshchestva, Moskva, 1-4 aprelya 2014 g.) [Russian Manufacturing Operations of Foreign Corporations: Global Management Practices and Impact on Local Institutions (Paper presented at the the 15th April International Scientific Conference on the Development of Economics and Society, Moscow, April 1-4, 2014)], Moscow: HSE (in Russian).

Gurkov I., Kossov V.V. (2014) Combining contemporary and Soviet-era management practices to achieve excellence at Knauf CIS. Global Business and Organizational Excellence, vol. 33, no 6, pp. 21-34.

Gurkov I., Morgunov E. (2015) Pereezd proizvodstva. Moment istiny, ili kak rabotnikam byl predostavlen pochti tselyi god, chtoby opredelit'sya so svoim resheniem o pereezde proizvodstva [Moving production. The moment of truth, or how the workers were given almost a year to decide on their decision to move production]. Upravlenie personalom [Personnel Management], no 12 (328), pp. 37-46 (in Russian).

Gurkov I.B. (2008) Strategiya i struktura korporatsii (2-e izd.) [The Strategy and Structure of the Corporation (2nd ed.)], Moscow: Delo Publishing House (in Russian).

Harzing A.-W., Pudelko M. (2016) Do we need to distance ourselves from the distance concept? Why home and host country context might natter more than (cultural) distance. Management International Review, vol. 56, no 1, pp. 1-34.

Henderson B. (1984) Logic of Business Strategy, New York: Harper Collins.

Hernández V., Nieto M.J. (2015) The effect of the magnitude and direction of institutional distance on the choice of international entry modes. Journal of World Business, vol. 50, no 1, pp. 122-132.

Johnson D.K.N., Siripong N., Brown A.S. (2009) The demise of distance? The declining role of physical proximity for knowledge transmission. Growth and Change, vol. 37, no 1, pp. 19-33. 
Kostova T., Nell P.C., Hoenen A. (2017) Understanding agency problems in headquarters-subsidiary relationships in multinational corporations: A contextualized model. Journal of Management, vol. 3, no 1, pp. 57-81. DOI: 10.1177/0149206316648383. Available at: http://dx.doi.org/10.1177/0149206316648383, accessed 17.12.2017.

Lazareva E. (2015) Vnedrenie sistemy transfertnogo tsenoobrazovaniya v Rossii [The System of Transfer Pricing in Russia Implementation]. Universum: Ekonomika i Yurisprudentsia (elektronnyi nauchnyi zhurnal) [Universum: Economics and Law (electronic journal], no 6 (17). Available at: http://7universum.com/ru/economy/archive/ item/2176, accessed 14.11.2016 (in Russian).

McDermott M.C. (2010) Foreign divestment. International Studies of Management and Organization, vol. 40, no 4, pp. 37-53.

Merchant H., Tung R.L., Verbeke A. (2012) The tenuous link between cultural distance and international strategy: Navigating the assumptions of cross-cultural research. Handbook of Research on International Strategic Management (eds. H. Merchant, R.L. Tung, A. Verbeke), Cheltenham: Edward Elgar, pp. 310-327.

Murphy J., Ackroyd S. (2013) Transnational corporations, socio-economic change and recurrent crisis. Critical Perspectives on International Business, vol. 9, no 4, pp. 336-357.

Nippa M., Pidun U., Rubner H. (2011) Corporate portfolio management: Appraising four decades of academic research. Academy of Management Perspectives, vol. 25, no 4, pp. 50-66.

PepsiCo Inc. (2015) Edited Transcript PEP - Q1 2015 PepsiCo Inc Earnings Call. Available at: http://www.pepsico. com/docs/album/Investor/q1_2015_pep_transcript_jzerxrllbnw4hsb.pdf?sfvrsn=0, accessed 27.10.2016.

Pereslegin S. (1999) Mirovaya voina i krizis evropeiskogo voennogo iskusstva [The World War and the Crisis of European Military Art] // Entsiklopediya voennogo iskusstva (ed. B. Liddel-Gart), Moscow: AST Publishing; Saint-Petersburg: Terra Fantastica, pp. 464-493 (in Russian).

Phillips N., Tracey P., Karra N. (2009) Rethinking institutional distance: Strengthening the tie between new institutional theory and international management. Strategic Organization, vol. 7, no 3, pp. 339-348.

Rust D.R. (1994) The budgeting process in a multinational firm. Multinational Business Review, vol. 2, no 2, pp. 59-63.

Salomon R., Wu Z. (2012) Institutional distance and local isomorphism strategy. Journal of International Business Studies, vol. 43, no 4, pp. 343-367.

Schönbohm A., Zahn A. (2016) Reflective and cognitive perspectives on international capital budgeting. Critical Perspectives on International Business, vol. 12, no 2, pp. 167-188.

Song S. (2014) Unfavorable Market Conditions, Institutional and Financial Development, and Exits of Foreign Subsidiaries. Journal of International Management, vol. 20, no 2, pp. 279-289.

Stahl G., Tung R., Kostova T., Zellmer-Bruhn M. (2016) Widening the lens: Rethinking distance, diversity, and foreignness in international business research through positive organizational scholarship. Journal of International Business Studies, vol. 47, no 6, pp. 621-630.

Xu D., Shenkar O. (2002) Institutional distance and the multinational enterprise. Academy of Management Review, vol. 27, no 4, pp. 608-618. 